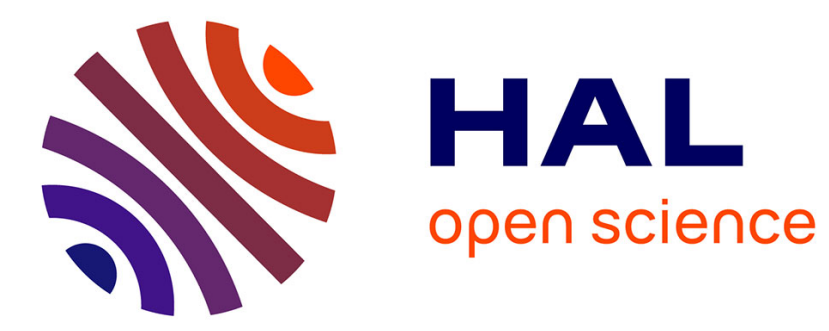

\title{
Committee Decision-making in the Council of the European Union
}

\author{
Frank M. Häge
}

\section{To cite this version:}

Frank M. Häge. Committee Decision-making in the Council of the European Union. European Union Politics, 2007, 8 (3), pp.299-328. 10.1177/1465116507079539 . hal-00571747

\section{HAL Id: hal-00571747 https://hal.science/hal-00571747}

Submitted on 1 Mar 2011

HAL is a multi-disciplinary open access archive for the deposit and dissemination of scientific research documents, whether they are published or not. The documents may come from teaching and research institutions in France or abroad, or from public or private research centers.
L'archive ouverte pluridisciplinaire HAL, est destinée au dépôt et à la diffusion de documents scientifiques de niveau recherche, publiés ou non, émanant des établissements d'enseignement et de recherche français ou étrangers, des laboratoires publics ou privés. 


\section{EUP}

European Union Politics

DOI: $10.1177 / 1465116507079539$

Volume 8 (3): 299-328

Copyright@ 2007

SAGE Publications

Los Angeles, London, New Delhi and Singapore

\section{KEY WORDS}

- bureaucratic discretion

- committee decision-making

- Council of the European Union

- delegation

- socialization
Committee Decision-making in the Council of the European Union

\author{
Frank M. Häge \\ Leiden University, The Netherlands
}

\section{ABSTRACT}

Committees of national officials play a major role in the decision-making of the European Union's main legislative body, the Council of Ministers. The study investigates the conditions under which bureaucrats decide on legislative dossiers without direct involvement of ministers. A statistical analysis is performed to examine this question, using an original data set of 439 legislative proposals. The results of the analysis indicate that formal institutional features such as the voting rule in the Council and the involvement of the European Parliament affect committee decision-making, whereas no effects of committee socialization and preference divergence among member states are identified. The results diminish concerns about the democratic legitimacy of Council decision-making to some extent, as the findings demonstrate that bureaucrats tend to decide only the less salient and more complex proposals. 


\section{Council committees as law-makers}

Many legislative decisions made in the European Union (EU) are not decided or even discussed by ministers in the Council. Although precise estimates vary, it is clear that a majority of legal acts are de facto adopted by bureaucrats in the various working groups and committees of the Council without any direct involvement of ministers (Häge, 2006; Hayes-Renshaw and Wallace, 2006: 53; Van Schendelen, 1996). The study examines the conditions under which legislative decisions are made by committees. By studying the explanatory power of different theoretical perspectives, the paper sheds light on the characteristics of Council committee negotiations. What kind of issues do committees decide? Do committees deal only with technical matters, as many practitioners and observers contend (Fouilleux et al., 2005; Spence, 2004)? Are committee members just stand-in negotiators for their ministers or do they have leeway to pursue their own goals? Does political conflict among committee members' principals or between the Council and other institutions affect the committee's decision-making capacity? Do national officials become socialized through their interaction in Council committees and take on more supranational attitudes that facilitate negotiations (Lewis, 1998, 2005)?

These kinds of question have largely been neglected in previous studies. Most theoretical and empirical research on legislative decision-making in the EU treats member states as unitary actors. Despite bureaucrats' important function in keeping the Council machinery running, their role in Council committees has hardly been examined. ${ }^{1}$ The current study contributes to filling this gap in the literature by investigating the factors that influence committee decision-making through a systematic quantitative analysis. The analysis relies on a novel data set that combines information on proposal characteristics, government party positions and features of the decisionmaking process for 439 legislative dossiers introduced by the Commission between 1 July 2000 and 1 January 2004.

The paper is structured as follows. First, the existing literature related to the research question is reviewed. The second section describes the role of committees in the decision-making process of the Council. This description is followed by a discussion of what counts as a committee decision for the purpose of this study. The subsequent theoretical section discusses potential explanatory factors for committee decision-making and derives testable hypotheses. The next two sections describe the research design and present the results of the statistical analysis. The paper concludes with a summary of the findings. 


\section{Literature review}

Several strands of existing research on EU policy-making are related to the research question. First, a growing body of empirical work examines the conflict structure underlying Council negotiations. Beyers and Dierickx (1997, 1998), Elgström et al. (2001), Kaeding and Selck (2005), Mattila and Lane (2001), Selck (2005), Thomson et al. (2004) and Zimmer et al. (2005) find evidence for a division between Northern and Southern member states. In contrast, Hagemann (2005) and Mattila (2004) identify the left-right ideology of governments as one of the main dimensions of contestation in the Council. Yet other studies find no recurrent coalition patterns at all but point instead to issue-specific and member-state-specific reasons for disagreement (HayesRenshaw et al., 2006; see also Thomson et al., 2004; Zimmer et al., 2005).

A second strand of research employs formal models to shed light on decision-making in the Council and in the EU in general. Policy positions or preferences of actors are common explanatory factors in all of these models. Procedural models also consider formal institutional features of the decisionmaking process to be of relevance (e.g. Crombez, 1996, 1997; Steunenberg, 1994; Tsebelis, 1994). In contrast, bargaining models stress the power resources of actors and the importance actors attach to an issue (e.g. Arregui et al., 2006). Empirical tests of these models indicate that bargaining models perform relatively better than procedural models in predicting the outcome of EU decision-making processes (Schneider et al., 2006). ${ }^{2}$

A third strand of research focuses on macro characteristics of Council decision-making processes, such as the efficiency of decision-making and the extent of policy change. Studies on decision-making efficiency focus primarily on the impact of institutional rules on Council negotiations. Both the studies by Golub (1999) and Schulz and König (2000) find that the possibility of adopting legislation by qualified majority voting increases the speed with which a decision is made in the Council. However, a recent study by Drüner et al. (2006) identifies the level of political conflict rather than the formal voting rule to be an important factor influencing decision-making efficiency. The same study also finds a substantial impact of political conflict on the extent of policy change accepted in the Council.

A fourth thread of work examines issues of delegation and discretion in the EU (Franchino, 2005; Pollack, 1997). A common argument in these studies is that less-informed politicians delegate decision-making authority to bureaucrats to benefit from the bureaucrats' higher level of expertise. The results of several empirical studies (Franchino, 2000, 2004) support the thesis that the extent of discretion granted to bureaucrats in charge of policy implementation increases with the degree of preference convergence between 
bureaucrats and politicians and with the uncertainty surrounding the practical consequences of legal provisions. A similar logic underlies the informational theory of legislative organization (Krehbiel, 1992). According to this theory, parliamentary committees are established by the full plenary to take advantage of the expertise acquired by the specialized committee members. How much discretion the plenary is willing to grant to the committee depends on the degree of uncertainty and the extent of preference convergence of the two bodies. In the EU context, hypotheses based on the informational theory of legislative organization are supported by studies of European Parliament (EP) committees and their members (Kaeding, 2004; McElroy, 2006).

Finally, another body of literature investigates the role perceptions of bureaucrats representing member states in meetings of Council committees. The results of these studies support the notion that committee members hold supranational role perceptions that complement their identities as government representatives (e.g. Egeberg et al., 2003). The findings in Egeberg (1999) and Trondal $(2001,2002)$ also support the view that supranational role perceptions are the result of socialization that occurs through interaction in committees at the European level. However, the studies by Beyers $(1998,2005)$ indicate that national factors play a more prominent role in shaping the attitudes of officials towards the EU than social interaction at the European level.

The discussed literature points to factors that might also be of relevance for explaining committee decision-making. First, the work on the Council's conflict structure and on formal models of Council decision-making directs attention to the importance of policy preferences and political conflict. Secondly, procedural models as well as the studies on decision-making efficiency and policy change point to the potential effects on committee decision-making of formal institutional features of the legislative process. Thirdly, the delegation literature indicates that policy uncertainty and the associated discretion might be factors explaining committee decision-making. Finally, the work on supranational role perceptions suggests that the behaviour of bureaucrats might be affected by the consequences of socialization in Council committees. The theory section discusses the causal mechanisms underlying these factors in more detail. The next two sections, respectively, describe the role of committees in the legislative decision-making of the Council and discuss the issues involved in measuring the level at which a decision is reached in the Council.

\section{The role of committees in Council decision-making}

What is generically referred to as 'the Council' is in reality a hierarchically and horizontally divided organization. Horizontally, the Council is divided into 
nine formations according to different policy areas. Hierarchically, the Council consists of three basic levels: the working parties at the bottom, the Committee of Permanent Representatives (Coreper) in the middle and the different formations of ministers at the top. Each of these levels is involved in the decisionmaking process of the Council.

After the Commission transmits a proposal to the Council, the proposal is first considered by the relevant working party. Officially, about 160 of these specialized groups exist. ${ }^{3}$ The membership of working parties is composed of government representatives, who are attached either to the permanent representations in Brussels or to national ministries or agencies. As a general rule, representatives of the member state holding the rotating Council Presidency chair the meetings of working parties. The Commission is also represented in working parties in order to introduce, explain and defend its proposal. All working party members are experts in a certain policy field, but the coverage of topics varies widely among groups, ranging from only 2 groups handling all matters pertaining to environmental policy to about 25 groups dealing with specific aspects of agricultural policy. A proposal is often discussed during several meetings of a working party. If all issues can be resolved by the working party, bodies at higher levels of the Council do not discuss the dossier any further. In this case, the dossier forms an A-point on the agenda of a forthcoming ministerial meeting. These A-points are not discussed by ministers but are adopted en bloc at the beginning of the meeting.

If the working party members cannot reach full agreement about the content of the dossier, the working party's chair sends the dossier up the hierarchy to one of the two formations of Coreper. The dossier is usually accompanied by a report describing the progress of negotiations and outlining the remaining problematic points. The permanent representatives themselves meet in Coreper II, which deals with proposals in the more 'political' policy fields such as General Affairs and External Relations (GAER), Justice and Home Affairs, and Economic and Financial Affairs. The deputies of the permanent representatives meet in Coreper I, which handles the dossiers in the remaining, more 'technical' policy areas. If Coreper can resolve the outstanding issues, the dossier is again adopted by ministers as an A-point without discussion. The dossier becomes a B-point on the agenda to be discussed by ministers only when both the working party and Coreper fail to reach complete agreement.

The preceding description is a rather stylized account of decision-making in the Council. In reality, a proposal can repeatedly travel up and down one or several layers of the Council hierarchy before a final decision is reached. In addition, the legislative process might not end after the first Council decision when the co-decision procedure applies. The internal decisionmaking process of the Council may repeat itself when the Council's common 
position has to be reconsidered in the light of new amendments made by the $\mathrm{EP}$ in the second reading of the co-decision procedure.

\section{What counts as a committee decision?}

The above discussion indicates that the identification of the decision-making level in the Council is not a trivial task and warrants some discussion. The study examines only first-reading decisions of the Council to assure a homogeneous sample of cases. In cases where the consultation procedure applies, the EP can give only a non-binding opinion and the Council's first-reading decision coincides with the adoption or rejection of the proposal. In contrast, the co-decision procedure grants far-reaching amendment and veto rights to the EP and allows for up to three readings of the proposal by both institutions. The Council can adopt a proposal in its first reading only if it accepts all of the EP's first-reading amendments. Otherwise, the Council's first-reading decision corresponds to a rejection of the proposal or, most commonly, to the adoption of a so-called 'common position'. The Council's common position then forms the basis of the EP's deliberations in the second reading. The study focuses on first-reading decisions of the Council because the legislative process after the first reading is mainly about resolving the conflict between the Council as a whole and the EP, not about reaching an agreement within the Council. The view that the Council's main decision is made in the first reading is also reflected in the fact that co-decision dossiers are almost exclusively managed by Coreper and working parties after a common position has been reached in the Council. Ministers rarely get involved in second-reading discussions or conciliation committee negotiations (Bostock, 2002). ${ }^{4}$

Although some of the theoretical arguments presented below apply primarily to the work of working parties rather than of Coreper, the analysis neglects the distinction between these two levels and focuses only on the division between ministers and committees in general. Several reasons justify this choice. Regarding the democratic legitimacy of Council decision-making, the distinction between ministers and bureaucrats in general is more relevant than the division between different layers of committees. Secondly, Coreper makes only about one-fifth of the Council's legislative decisions; the remaining proposals are decided either by working parties or by ministers (Häge, 2006). Finally, the bureaucratic level at which a proposal was decided is very difficult, if not impossible, to identify for a large number of proposals. In contrast, information on whether or not a proposal was ever discussed by ministers is relatively easy to obtain in a reliable manner.

Even with a limitation to the divide between the political and bureaucratic levels, the identification of the level at which a particular proposal was 
Table 1 Decision-making level by Council formation

\begin{tabular}{|c|c|c|c|}
\hline Council formation & Committee & Ministers & Total \\
\hline Culture & $\begin{array}{c}5 \\
(83.3)\end{array}$ & $\begin{array}{c}1 \\
(16.7)\end{array}$ & $\begin{array}{c}6 \\
(100.0)\end{array}$ \\
\hline Education and Youth & $\begin{array}{c}2 \\
(22.2)\end{array}$ & $\begin{array}{c}7 \\
(77.8)\end{array}$ & $\begin{array}{c}9 \\
(100.0)\end{array}$ \\
\hline Agriculture & $\begin{array}{c}48 \\
(53.9)\end{array}$ & $\begin{array}{c}41 \\
(46.1)\end{array}$ & $\begin{array}{c}89 \\
(100.0)\end{array}$ \\
\hline Fisheries & $\begin{array}{c}20 \\
(54.0)\end{array}$ & $\begin{array}{c}17 \\
(46.0)\end{array}$ & $\begin{array}{c}37 \\
(100.0)\end{array}$ \\
\hline Economic and Finance & $\begin{array}{c}32 \\
(65.3)\end{array}$ & $\begin{array}{c}17 \\
(34.7)\end{array}$ & $\begin{array}{c}49 \\
(100.0)\end{array}$ \\
\hline Environment & $\begin{array}{c}7 \\
(19.4)\end{array}$ & $\begin{array}{c}29 \\
(80.6)\end{array}$ & $\begin{array}{c}36 \\
(100.0)\end{array}$ \\
\hline Justice and Home Affairs & $\begin{array}{c}17 \\
(46.0)\end{array}$ & $\begin{array}{c}20 \\
(54.0)\end{array}$ & $\begin{array}{c}37 \\
(100.0)\end{array}$ \\
\hline Transport and Telecommunications & $\begin{array}{c}4 \\
(5.8)\end{array}$ & $\begin{array}{l}65 \\
(94.2)\end{array}$ & $\begin{array}{c}69 \\
(100.0)\end{array}$ \\
\hline Industry and Energy & $\begin{array}{c}2 \\
(11.1)\end{array}$ & $\begin{array}{c}16 \\
(88.9)\end{array}$ & $\begin{array}{c}18 \\
(100.0)\end{array}$ \\
\hline Research & $\begin{array}{c}2 \\
(16.7)\end{array}$ & $\begin{array}{c}10 \\
(83.3)\end{array}$ & $\begin{array}{c}12 \\
(100.0)\end{array}$ \\
\hline Internal Market, Consumers, Tourism & $\begin{array}{c}23 \\
(44.2)\end{array}$ & $\begin{array}{c}29 \\
(55.8)\end{array}$ & $\begin{array}{c}52 \\
(100.0)\end{array}$ \\
\hline Employment and Social Affairs & $\begin{array}{c}2 \\
(11.8)\end{array}$ & $\begin{array}{c}15 \\
(88.2)\end{array}$ & $\begin{array}{c}17 \\
(100.0)\end{array}$ \\
\hline Health & $\begin{array}{l}0 \\
(0.00)\end{array}$ & $\begin{array}{c}8 \\
(100.0)\end{array}$ & $\begin{array}{c}8 \\
(100.0)\end{array}$ \\
\hline Total & $\begin{array}{l}164 \\
(37.4)\end{array}$ & $\begin{array}{l}275 \\
(62.6)\end{array}$ & $\begin{array}{c}439 \\
(100.0)\end{array}$ \\
\hline
\end{tabular}

Note: The numbers in brackets give row percentages. The sample is restricted to legislative proposals that regulate internal EU policies and were introduced by the Commission between 1 July 2000 and 1 January 2004. See text for the precise sample selection criteria. A proposal was coded as having been decided at the ministerial level when it had been debated by ministers at some stage during Council negotiations and as having been decided by a committee otherwise. Source: Own data based on information from Prelex and Council documents.

decided is not straightforward. Given the focus of this study on decisions by committees, the study opts for the most restrictive measure in this respect. Only dossiers that showed no direct involvement of ministers were coded as having been decided by a committee. Proposals that were at some stage discussed in ministerial meetings were not coded as committee decisions, even when the dossier was subsequently referred back to the committee with further instructions and eventually decided by the committee. ${ }^{5}$ The results of 
this coding procedure can be seen in Table 1 . The table shows considerable variation across Council formations in the number of dossiers decided at a particular level. Although different Council formations as such do not constitute an explanation of why a proposal is decided at the committee level, the table illustrates the wide variation in committee decision-making, which calls for an explanation.

\section{Theoretical perspectives and hypotheses}

The literature review pointed to preferences, formal institutions, socialization and uncertainty as factors that are potentially of relevance for explaining committee decision-making. This section discusses the theoretical arguments underlying these factors in more detail. The section also addresses the potential influence of political salience, a factor that has been largely neglected in previous research. Testable hypotheses are derived for each of these factors. The theories underlying the proposed effects of preferences and formal institutions retain the assumption of member states as unitary actors. In these theories, agreement reached at the committee level is simply an indicator of the efficiency of Council decision-making and is not related to specific characteristics of the committee or its members. In contrast, the perspectives theorizing effects of socialization, uncertainty and salience assume that characteristics of Council committees and their members play a significant role in explaining committee decision-making.

\section{Policy preferences}

In most explanations of Council decision-making, policy preferences play an important role. Schneider et al. (2006) distinguish between procedural models that stress formal rules for aggregating actors' preferences (e.g. König and Pöter, 2001; Selck and Steunenberg, 2004; Tsebelis and Garrett, 2000; for reviews, see Dowding, 2000; Hörl et al., 2005) and theories that emphasize informal bargaining processes as important for translating individual preferences into group decision-making outcomes (e.g. Arregui et al., 2004; Bailer, 2004). In either case, political actors are assumed to care primarily about policy outcomes, for either ideological or electoral reasons. Because most of these models assume complete information, they do not yield direct predictions about the difficulty of reaching an agreement in the Council. A proposal is either instantly accepted or rejected. However, the expectation that a larger divergence of preferences among actors makes it harder to reach an agreement is in line with the general reasoning underlying these models (see Drüner et al., 2006; Schulz and König, 2000). 
The models consider member states as unitary actors. Implicitly, national officials negotiating in Council committees are regarded as perfect agents of their political masters. National officials represent the interests of their minister and act accordingly. Interactions in committees are supposed to mirror those at the political level and bureaucrats have no effect on negotiation outcomes independent of the will of their political superiors. In short, bureaucrats act as stand-in negotiators for their ministers according to these models. Therefore, preference divergence among ministers should also have an adverse effect on the chances that agreement is reached on the committee level:

H1: The less diverse ministers' policy preferences, the more likely a decision is reached at the committee level.

\section{Institutions}

Both the procedural and the bargaining models take formal institutional structures into account (Schneider et al., 2006). In the bargaining perspective, formal institutions shape the setting in which negotiations take place and may determine the bargaining strength of different actors. However, the mechanism through which decisions are reached remains bargaining. In procedural models, formal institutions determine not only the relevant actors and their power resources, but also the aggregation of individual preferences into collective decisions. The Council's voting rule is of particular relevance in this respect (e.g. Crombez, 1996, 1997; Steunenberg, 1994; Tsebelis, 1994; for a discussion of this point, see Mattila and Lane, 2001). If only a qualified majority of member states is needed to adopt a measure rather than agreement by all member states, a decision about policy change is reached more easily in the Council. Given that member states are considered to be unitary actors, the voting rule should have the same effect on decision-making at the committee level:

H2a: The lower the voting threshold in the Council, the more likely a decision is reached at the committee level.

Even if actual voting is mainly restricted to the ministerial level, the mere possibility of a vote being taken later by ministers should result in more flexible negotiating positions in committees. When the unanimity rule applies, each member state knows that no legislation will be adopted without its approval. A patient member state can simply stick to its initial position, trying to extract concessions from member states that are more eager to change policy. When qualified majority voting applies, it might be more beneficial for member states to influence an early compromise solution found in committee negotiations than to stick with their original position and risk eventually being outvoted at the ministerial level. 
The expected voting rule effect is mainly based on the reasoning in procedural models, but the legislative procedure is also consequential in bargaining models. The co-decision procedure essentially empowers an additional player, the European Parliament, with a veto right. Thus, even if the decision-making mechanism is bargaining rather than voting, the views of an additional actor have to be taken into account in order to reach an overall agreement. Although the EP does not take part in Council deliberations directly, the EP can exert indirect influence on Council negotiation in a number of ways. First, more and more efforts are made to reach an early agreement between the Council and the EP in the first reading. In order to reach an early agreement, at least some of the EP's views have to be incorporated in the Council's first-reading decision. Even if no attempts are made to bring the procedure to a close in the first reading, member states might anticipate that the Council's first-reading decision constitutes only a preliminary step in shaping the eventual policy outcome. Aware that the Council's common position forms only the base for a later compromise with the EP, member states with positions very distant from those of the Parliament have reasons to be more reluctant to make concessions. Secondly, the amendments proposed by the EP might direct attention to latently conflictual issues that would not have been considered by member states otherwise (see e.g. Rittberger, 2000). Finally, the EP's position might bolster the case of a member state and give additional legitimacy to the state's position, thereby also making it more unwilling to compromise in Council negotiations. Given a greater reluctance of member states to make concessions, an agreement at the committee level is expected to be less likely:

H2b: The less involvement of the European Parliament, the more likely a decision is reached at the committee level.

\section{Committee socialization}

A growing field of research considers the socializing effects of international institutions (e.g. Checkel, 2003; Hooghe, 2005; Johnston, 2001). As the literature review has shown, this field is also one of the few areas where research has directly focused on Council committees and their members. Several quantitative studies have analysed to what extent committee members invoke supranational role perceptions and how far these role perceptions can be attributed to interaction in committees (Beyers, 1998, 2005; Egeberg, 1999; Trondal, 2001, 2002). The general argument is simple: working in EU institutions exposes people to supranational norms and values and thus makes them more prone to adopt these views. 
Qualitative studies find that the socialization of committee members also influences decision-making behaviour (Lewis, 1998, 2005). Bureaucrats' more supranational outlook is thought to foster a commitment to joint problemsolving and to reduce the propensity to pursue individualist state interests. According to this view, socialization cannot be equated with a simple change in policy preferences. Socialization occurs at a more general cognitive level. The result of socialization is not a change in specific policy positions, but a change in the standards according to which different policy options are evaluated and a change in the norms perceived to define acceptable behaviour in committee negotiations. The most likely result of socialization in the context of the Council is a valuation of the Council's decision-making process itself (Lewis, 2005: 939), rather than a shift in bureaucrats' specific policy positions towards more supranational preferences. Thus, socialization does not necessarily result in more supranational policy outcomes, but it does induce more cooperative behaviour in negotiators as a result of common efforts to keep the Council machinery running. More cooperative behaviour should make agreement in committees more likely. Socialization into supranational norms and values works through social interaction in international settings. Thus, the more time bureaucrats spend in Brussels interacting with their peers from other countries, the more likely they are to develop and adopt a dense net of norms and values governing appropriate behaviour in committee negotiations.

H3: The higher the committee meeting density, the more likely a decision will be reached at the committee level.

The transfer and adoption of norms and values can occur through a variety of mechanisms, including normative suasion, social mimicking, shaming and communication (Hooghe, 2005: 865). However, the more time individuals spend in international settings, the more likely it is that these mechanisms are effective in changing the norms and values held by them. Committee meeting density refers not to the number of committee meetings at a particular point in time, but to a more structural characteristic of Council committees. Some of these committees meet on a regular basis several times per month and deal with all issues falling in a certain policy area (e.g. the environment committee), whereas others are highly specialized and meet only when the need arises to discuss a specific proposal (e.g. many working parties dealing with the common agricultural policy).

Note that the hypothesis is not intended to test possible socializing effects of other international or domestic organizations that might also lead to changes in the norms and values held by bureaucrats (see Beyers, 2005; Hooghe, 2005). Although socialization in other organizations might influence 
the attitudes of bureaucrats taking part in committee negotiations, these experiences affect individual committee members in different ways. Given that committee members have relatively unique career histories, socialization in other organizational settings is not expected to affect committee decisionmaking in a systematic manner. Thus, the current analysis examines only the 'strong socialization hypothesis' (Beyers, 2005: 901), which asserts that social interactions in international institutions lead to changes in actor characteristics. More precisely, the analysis tests whether the interaction in Council committees leads to changes in the values and norms that bureaucrats hold and that affect their negotiating behaviour. ${ }^{6}$

Whereas the socialization approach theorizes why bureaucrats might be more or less able to reach agreement at the committee level, the remaining two perspectives take the opposite view and discuss the conditions under which politicians are willing to delegate decision-making authority to bureaucrats rather than examine legislative proposals themselves.

\section{Uncertainty}

Delegation theories point to uncertainty about the practical consequences of legal provisions as an important reason for principals to transfer decisionmaking authority to better-informed agents (Bendor et al., 2001). For example, the informational theory of legislative organization argues that parliaments establish committees and delegate far-reaching decision-making powers to them in order to reap the policy benefits accruing from the on average more favourable decisions made owing to the specialized knowledge of committee members (Krehbiel, 1992: 3-6; for empirical studies in an EU context, see Kaeding, 2004; McElroy, 2006). The sectorally specialized committee structure of the Council resembles the structure of parliamentary committees in many respects. The assumption that members of Council committees are better informed than ministers about the actual consequences of legislative acts is also seems reasonable (see also Hoyland, 2006). Considering that committee members are directly accountable to their ministers, the potential for bureaucratic drift is limited in the Council, too. The limited potential for bureaucratic drift gives ministers enough incentive to delegate decision-making authority to Council committees in order to exploit their informational advantages. An important finding of the informational theory of legislative organization, and of most other delegation theories, is that more decision-making authority will be delegated in the face of higher uncertainty about policy outcomes. In the context of the Council, ministers should therefore be more likely to leave a decision to the committee in cases where a proposal is concerned with regulating issues whose consequences are highly uncertain. 
H4: The more uncertain the practical consequences of legal provisions, the more likely a decision will be reached at the committee level.

Whereas this approach stresses the informational advantages of bureaucrats in making policy decisions, the last perspective emphasizes the limitations of ministers in terms of time and resources.

\section{Salience}

Besides the lack of expertise, politicians' organizational and natural resource constraints might also be reasons for delegation. Law-makers have only a certain amount of time available that they can devote to scrutinizing and discussing legislation (Cox, 2006: 142). Even where information about policy outcomes is complete, drafting legislation takes time and effort that cannot be spent on other purposes (Huber and Shipan, 2002: 79). Uncertainty about the preferences of other legislators, rather than about the policy outcome, might also be of importance here. The very process of decision-making, that is, building coalitions and reaching agreements, becomes rather costly in such circumstances (Cox and McCubbins, 2006: 306). Extending the size of the legislature is also not an option, at least not in the short run (Epstein and O'Halloran, 1999: 44). Therefore, legislators are expected to prioritize. Ministers are likely to focus their attention on the dossiers that promise them the highest benefits in terms of re-election chances and to delegate decisionmaking authority for other dossiers (Epstein and O'Halloran, 1999: 47; Franchino, 2004). The perceived importance of a dossier is usually connected to its expected consequences for core constituencies, powerful organized interests or the public at large. Thus, ministers should be more likely to take up politically salient proposals that have a larger effect on the ministers' chances of being re-elected. Conversely, committees should have more leeway to reach an agreement when the issue is less important.

H5: The lower the salience of a legislative dossier, the more likely a decision will be reached at the committee level.

\section{Data collection, case selection and operationalization}

The empirical part of the study consists of a statistical analysis of the decisionmaking level in the Council. The analysis is based on a sample of 439 legislative dossiers. The dossiers are selected according to several criteria. First, only proposals transmitted to the Council and the Parliament between 1 July 2000 and 1 January 2004 are considered. The focus on recent years ensures 
that the information necessary to conduct the analysis is publicly available. As the observation period ends on 1 January 2005, the selection procedure allows the fate of a proposal to be followed for at least one year after its introduction by the Commission. The problem of censored observations is thereby reduced. Second, only proposals to be decided according to the co-decision or consultation procedure are included in the sample. These two procedures are currently the most widely used procedures to regulate decision-making on substantial policy initiatives. The two selection criteria resulted in an initial sample of 809 cases.

Proposals that were withdrawn by the Commission (26 proposals) and proposals on which no Council decision had been made by 1 January 2005 (96 proposals) were then excluded from the analysis. None of the proposals that were withdrawn by the Commission had ever been discussed at the ministerial level. Thus, committees seem to play an important role in that they screen proposals and establish whether the proposed policy change is acceptable to the Council in principle. However, a rather different logic of committee decision-making is likely to apply to cases in which the conflict is about the acceptability of any policy change rather than the precise form of the policy change. The theoretical perspectives and hypotheses outlined earlier refer to the Council level at which a decision is made, not to whether or not such a decision is made at all. The loss of the censored cases is unfortunate but unavoidable, given that information for the dependent variable is missing.

The remaining selection criteria are employed to yield a homogeneous sample of legislative dossiers that regulate the substance of internal EU policies. Therefore, the conclusion of international agreements (76 proposals) and proposals discussed by the Development (10 proposals) and GAER Council formations (15 proposals in external relations and 44 in general affairs) were discarded. Concluding international agreements is usually a pure formality and these acts are routinely handled at the committee level. The external relations part of GAER hardly deals with internal EU policies. The general affairs part of GAER is mostly concerned with administrative and institutional issues, not with substantive matters of policy. For the same reason, proposals discussed in the Budget Council formation (10 proposals) are excluded. Finally, all dossiers considered by the Council to be of a nonlegislative nature (58 proposals) or introduced by a member state rather than the Commission (35 proposals) were dropped from the sample. Overall, this selection procedure resulted in a final sample of 439 cases used in the analysis.

The dependent variable is measured through a dichotomous variable indicating whether or not the proposal had been decided at the committee level. The coding of the dependent variable employed the criteria discussed 
earlier. Information to generate this variable was extracted from Prelex, the Commission's database monitoring the decision-making process between EU institutions. ${ }^{7}$ Data on the applicable legislative procedure and actual EP involvement are also extracted from this source. The indicator for EP involvement is a dichotomous variable indicating whether or not the EP made any amendments under the co-decision procedure. Thus, the variable not only measures the formal powers of the EP under the co-decision procedure, but also takes into account whether the EP actually made use of these powers. Information on the voting rule was collected from the 'Monthly Summary of Council Acts' published by the Council. Where such information was not available, the voting rule was identified through the legal base of the proposal in conjunction with the appendix in Hix (2005), which lists the applicable voting rule and legislative procedure corresponding to the different articles of the EU treaties.

The preference divergence variable is based on data on the party composition of government cabinets and the parties' positions on different policy issues. The party position data were taken from the Chapel Hill 2002 expert survey (Hooghe et al., 2005). In contrast to other party position data sets (e.g. Benoit and Laver, 2006; Klingemann et al., 2006), the Chapel Hill indicators are specifically constructed to provide party positions on EU policy issues. Information on cabinet composition in the member state governments was collected from various editions of the Political Data Yearbook of the European Journal of Political Research. The party affiliation of government ministers and the corresponding policy positions were then linked to the different Council formations. As can be seen in Table 2, the correspondence between formations and policy positions is not one-to-one. Policy-specific party positions are available only for the main EU policy areas. Therefore, party positions on the internal market are also used as proxies for the positions on Transport and Telecommunications as well as Industry and Energy. Similarly, party positions on the social left-right dimension should be closely related to positions on Education and Youth as well as Culture.

In cases where several ministers of one government occupied portfolios that could all be related to one Council formation, the average party position of these ministers was used as the country's position. Otherwise, the minister's party position represented the country's position. For each Council formation, the preference divergence variable was calculated as the maximum difference between the countries' policy positions. ${ }^{8}$ Although party positions are constant, the measure varies both between and within Council formations. In part, this variation is owing to the different positions on different policy issues. However, much of the variation also stems from changes in the composition of government cabinets over time. 
Table 2 The linkage of Council formations with party policy positions

\begin{tabular}{ll}
\hline Council formation & Party position on policy dimension \\
\hline $\begin{array}{l}\text { Culture } \\
\text { Education and Youth }\end{array}$ & Social left-right \\
$\begin{array}{l}\text { Agriculture } \\
\text { Fisheries }\end{array}$ & Agricultural spending \\
Economic and Finance & \\
Environment & Internal market \\
Justice and Home Affairs & Environmental policy \\
$\begin{array}{l}\text { Transport and Telecommunications } \\
\text { Industry and Energy }\end{array}$ & Common policy on asylum \\
$\begin{array}{l}\text { Research } \\
\text { Internal Market, Consumers, Tourism }\end{array}$ & Internal market \\
Employment and Social Affairs & Employment policy \\
Health &
\end{tabular}

Note: The Council formations are based on the organization of the Council as of June 2000, excluding General Affairs and External Relations, Budget and Development (see text for further details). Data on the party positions on the policy dimensions are taken from the Chapel Hill 2002 expert survey (Hooghe et al., 2005).

The degree of exposure to supranational norms and values in committees is measured by the average number of days a committee met per month between 1 January 2000 and 31 December 2004. Information on the number of committee meetings was derived from the calendar of Council meetings maintained by the Council secretariat. To reflect the structural differences among committees rather than short-term fluctuations in their workload, the number of meetings is averaged over the whole time period rather than over months or over presidency periods.

A variable indicating whether or not the proposal provides for the establishment of a Comitology committee is used as a measure of the uncertainty surrounding the practical consequences of a dossier (see also Franchino, 2004). Comitology committees not only assist and advise but also control the Commission in implementing EU legislation. Previous research argues that the need for post hoc control of implementation tasks is stronger when legislators have diverse preferences (Franchino, 2000). Thus, the establishment of a Comitology committee could be an indicator either of the complexity of the policy matter or of political conflict among legislators. 
However, any possible effect of political conflict is controlled for in the statistical analysis through the inclusion of the preference divergence variable. Nevertheless, the analysis is repeated with an alternative uncertainty variable. This variable indicates whether the proposal has implications for one or several policy areas. The variable is based on the number of policy fields mentioned in the Prelex database. Anticipating the consequences of legal provisions that affect several policy areas should be more difficult than anticipating the consequences of legal provisions that affect only one policy area.

The salience of a dossier is assessed through the number of recitals contained in the proposal. Recitals outline and list the reasons for adopting a certain dossier. This measure is based on the assumption that the importance of a piece of legislation varies with the number of reasons given for its adoption. The more important a dossier, the larger the number of justifications given for its adoption. Actors are likely to value policy issues in different degrees, since they are more or less affected by decisions in different policy areas. Considering that the Commission drafts the initial proposal, the salience variable could be biased somewhat towards representing the valuations of this institution. However, given that the Commission is generally regarded as the promoter of European integration and the common European interest, the measure should give a good approximation of the importance of a proposal in the overall European legal order even if such an effect exists. Table 3 describes all the variables and their sources.

\section{Results of the statistical analysis}

A logistic regression is performed to examine the relationships between the independent variables and the Council decision-making level. The results of the analysis are presented in Table 4. A positive relationship in Table 4 indicates that higher values of the independent variable increase the likelihood that a decision will be made by a committee rather than by ministers. Models 1 and 2 show specifications based on the theoretical considerations discussed above. Models 3 and 4 add dummy variables to control for any unaccounted effects specific to policy-making in certain council formations.

The preference divergence variable does not show a statistically significant effect in any of the models. Political conflict among member states does not seem to influence the level at which a decision is taken in the Council. In contrast, the variable for EP involvement shows a rather strong and clear relationship in the expected direction. EP amendments under the co-decision procedure make a decision at the committee level less likely. The results regarding the voting rule variable are somewhat ambiguous. Although the 
Table 3 Description of variables and data sources

\begin{tabular}{|c|c|c|}
\hline Name & Description & Sources \\
\hline $\begin{array}{l}\text { Committee } \\
\text { decision- } \\
\text { making }\end{array}$ & $\begin{array}{l}\text { Dichotomous variable: } \\
0=\text { discussed by ministers } \\
1=\text { never discussed by } \\
\text { ministers }\end{array}$ & Prelex $^{a}$ and Council documents ${ }^{b}$ \\
\hline $\begin{array}{l}\text { Preference } \\
\text { divergence }\end{array}$ & $\begin{array}{l}\text { Distance between most } \\
\text { extreme policy positions } \\
\text { of ministers' parties }\end{array}$ & $\begin{array}{l}\text { Cabinets: Political Data } \\
\text { Yearbook, European Journal of } \\
\text { Political Research, 1999-2005; } \\
\text { Policy positions: Hooghe et al. } \\
\text { (2005) }\end{array}$ \\
\hline $\begin{array}{l}\text { Qualified } \\
\text { majority voting }\end{array}$ & $\begin{array}{l}\text { Dichotomous variable: } \\
0=\text { unanimity } \\
1=\text { qualified majority voting }\end{array}$ & $\begin{array}{l}\text { Monthly Summary of Council } \\
\text { Acts }^{c} \text {; appendix in Hix (2005: } \\
\text { 415) }\end{array}$ \\
\hline EP involvement & $\begin{array}{l}\text { Dichotomous variable: } \\
0=\text { consultation or no } \\
\text { amendment under co-decision } \\
1=\text { co-decision and amendment }\end{array}$ & Prelex \\
\hline $\begin{array}{l}\text { Committee } \\
\text { meeting density }\end{array}$ & $\begin{array}{l}\text { Average number of meeting } \\
\text { days per month between } \\
1 \text { January } 2000 \text { and } \\
31 \text { December } 2004\end{array}$ & $\begin{array}{l}\text { Calendars of working party } \\
\text { meetings maintained by the } \\
\text { Council Secretariatd, Council } \\
\text { documents }\end{array}$ \\
\hline $\begin{array}{l}\text { Comitology } \\
\text { committee }\end{array}$ & $\begin{array}{l}\text { Dichotomous variable: } \\
0=\text { no provision for committee } \\
1=\text { provision for committee }\end{array}$ & Commission proposals \\
\hline Policy areas & $\begin{array}{l}\text { Dichotomous variable: } \\
0=\text { one policy area } \\
1=\text { more than one policy area }\end{array}$ & Prelex \\
\hline Salience & Number of recitals & Commission proposals \\
\hline
\end{tabular}

a See the Prelex website: http://ec.europa.eu/prelex/apcnet.cfm?CL=en (consulted 22 August 2006).

b See the Council's public register of documents:

http://www.consilium.europa.eu/showPage.asp?id=254\&lang=en\&mode=g (consulted 28 February 2007).

' See the 'Monthly Summary of Council Acts' on the Council's website: http://www.consilium.europa.eu/cms3_applications/showPage.ASP?id=551\&lang=en\&mode=g (consulted 10 August 2006).

${ }^{d}$ The calendars were obtained through a request for access to Council documents; see http://www.consilium.europa.eu/cms3_applications/showPage.asp?id=306\&lang=en\&mode=g (consulted 22 February 2007). 
coefficient of the voting rule variable shows the expected sign in all models, the relationship is only statistically significant in the models including the dummy variables for different Council formations.

The committee socialization hypothesis is not supported by the data analysis. The coefficient of the socialization variable indicates a statistically significant negative relationship in the models excluding Council formation controls. This finding is clearly contrary to expectations. Although the coefficient changes its sign when dummy variables for Council formations are introduced, the relationship is not statistically significant. In contrast, uncertainty about the practical consequences of a proposal seems to have the expected effect on committee decision-making. Models 1 and 3 indicate a substantial increase in the likelihood that a decision is made at the committee level when the dossier proposes the establishment of a Comitology committee. Models 2 and 4 reproduce this result with the alternative measure of uncertainty indicating whether a proposal concerns one or several policy areas, respectively. The salience of the dossier also seems to be of importance for determining at which Council level a dossier is decided. The variable measuring the salience of a dossier demonstrates a strong negative and statistically significant relationship with the dependent variable.

In order to control for any unaccounted effects specific to policy-making in certain Council formations, models 3 and 4 include dummy variables for the different formations. The Employment and Social Affairs formation was merged with the Health formation because of the small number of proposals debated in the latter. All eight Health proposals were in fact discussed by ministers. A dummy variable for the Health Council formation would have completely determined the value of the dependent variable and resulted in an exclusion of these observations from the statistical analysis.

The results of the significance tests indicate that a decision is more likely to be made at the committee level in the areas of Economic and Finance, Justice and Home Affairs, and Internal Market, Consumers and Tourism. However, these tests have to be interpreted with care. The statistical significance of all Council formation dummy variables depends crucially on the chosen reference category. Given its relatively moderate position, Industry and Research was used as the reference formation in the models presented in Table 5. However, the coefficients of other Council formation variables may be statistically significant when compared with a different reference category. In this respect, the relative sizes of the coefficients of the Council formation dummy variables are more informative than their statistical significance. The Council formations of Environment, Transport and Telecommunications, and Health, Employment and Social Affairs stand out for having relatively few decisions made at the committee level when considering also the sizes and 
Table 4 Determinants of committee decision-making: Logistic regression results

\begin{tabular}{|c|c|c|c|c|}
\hline & Model 1 & Model 2 & Model 3 & Model 4 \\
\hline Preference divergence & $\begin{array}{l}-0.19 \\
(1.51)\end{array}$ & $\begin{array}{l}-0.17 \\
(1.36)\end{array}$ & $\begin{array}{c}0.49 \\
(1.36)\end{array}$ & $\begin{array}{c}0.49 \\
(1.32)\end{array}$ \\
\hline Qualified majority voting & $\begin{array}{c}0.43 \\
(1.15)\end{array}$ & $\begin{array}{c}0.39 \\
(1.02)\end{array}$ & $\begin{array}{l}1.52 * * * \\
(2.81)\end{array}$ & $\begin{array}{l}1.59 * * * \\
(2.91)\end{array}$ \\
\hline EP involvement & $\begin{array}{l}-0.84^{* * *} \\
(2.66)\end{array}$ & $\begin{array}{l}-0.95^{* * *} \\
(2.95)\end{array}$ & $\begin{array}{l}-1.07 * * \\
(2.47)\end{array}$ & $\begin{array}{l}-1.18 * * * \\
(2.62)\end{array}$ \\
\hline Committee meeting density & $\begin{array}{l}-0.17 * * * \\
(2.91)\end{array}$ & $\begin{array}{l}-0.19 * * * \\
(3.21)\end{array}$ & $\begin{array}{c}0.25 \\
(1.26)\end{array}$ & $\begin{array}{c}0.24 \\
(1.20)\end{array}$ \\
\hline Uncertainty & & & & \\
\hline Comitology committee & $\begin{array}{r}0.51^{*} \\
(1.89)\end{array}$ & & $\begin{array}{r}0.60^{*} \\
(1.95)\end{array}$ & \\
\hline Policy areas & & $\begin{array}{l}0.71 * * * \\
(2.69)\end{array}$ & & $\begin{array}{l}0.97^{* * *} \\
(3.20)\end{array}$ \\
\hline Salience & $\begin{array}{l}-0.20^{* * *} \\
(7.52)\end{array}$ & $\begin{array}{l}-0.18^{* * *} \\
(7.75)\end{array}$ & $\begin{array}{l}-0.21^{* * *} \\
(7.27)\end{array}$ & $\begin{array}{l}-0.20^{* * *} \\
(7.48)\end{array}$ \\
\hline Council formation controls: & & & & \\
\hline Culture & & & $\begin{array}{c}1.84 \\
(1.02)\end{array}$ & $\begin{array}{c}2.38 \\
(1.30)\end{array}$ \\
\hline Education and Youth & & & $\begin{array}{l}-0.30 \\
(0.20)\end{array}$ & $\begin{array}{c}0.05 \\
(0.03)\end{array}$ \\
\hline Agriculture & & & $\begin{array}{c}0.07 \\
(0.05)\end{array}$ & $\begin{array}{c}0.39 \\
(0.29)\end{array}$ \\
\hline Fisheries & & & $\begin{array}{l}-0.78 \\
(0.58)\end{array}$ & $\begin{array}{l}-0.42 \\
(0.30)\end{array}$ \\
\hline Economic and Finance & & & $\begin{array}{l}3.31 * * * \\
(3.47)\end{array}$ & $\begin{array}{l}3.61 * * * \\
(3.73)\end{array}$ \\
\hline Environment & & & $\begin{array}{l}-1.84 \\
(0.99)\end{array}$ & $\begin{array}{c}-1.75 \\
(0.93)\end{array}$ \\
\hline Justice and Home Affairs & & & $\begin{array}{l}2.57^{* * *} \\
(2.68)\end{array}$ & $\begin{array}{l}3.14^{* * *} \\
(3.21)\end{array}$ \\
\hline Transport and Telecommunications & & & $\begin{array}{l}-1.60 \\
(1.44)\end{array}$ & $\begin{array}{l}-1.44 \\
(1.26)\end{array}$ \\
\hline Research & & & $\begin{array}{l}-0.03 \\
(0.02)\end{array}$ & $\begin{array}{c}0.30 \\
(0.26)\end{array}$ \\
\hline $\begin{array}{l}\text { Internal Market, Consumers, and } \\
\text { Tourism }\end{array}$ & & & $\begin{array}{l}2.58^{* * *} \\
(2.76)\end{array}$ & $\begin{array}{l}2.78 * * * \\
(2.94)\end{array}$ \\
\hline $\begin{array}{l}\text { Health, Employment and } \\
\text { Social Affairs }\end{array}$ & & & $\begin{array}{l}-1.27 \\
(0.88)\end{array}$ & $\begin{array}{l}-1.16 \\
(0.78)\end{array}$ \\
\hline Constant & $\begin{array}{l}2.62 * * * \\
(4.80)\end{array}$ & $\begin{array}{l}2.44^{* * *} \\
(4.38)\end{array}$ & $\begin{array}{l}-1.96 \\
(1.48)\end{array}$ & $\begin{array}{c}-2.56^{*} \\
(1.90)\end{array}$ \\
\hline Likelihood ratio Chi-squared & $161.38^{* * *}$ & $165.26 * * *$ & $226.81^{* * *}$ & $233.73 * * *$ \\
\hline Pseudo $R^{2}$ & .28 & .28 & .39 & .40 \\
\hline Adj. Count $R^{2}$ & .42 & .37 & .53 & .49 \\
\hline $\mathrm{BIC}$ & -2209.67 & -2213.55 & -2208.17 & -2215.09 \\
\hline
\end{tabular}

Notes: Absolute value of z statistics in parentheses, * significant at $10 \%,{ }^{*}$ significant at $5 \%$, *** significant at $1 \%$, two-sided tests, $\mathrm{N}=439$. The dependent variable is a dichotomous variable indicating whether the dossier was only discussed on the committee level (1) or also by ministers (0). 
signs of the coefficients. The differences in committee decision-making between at least some of the Council formations and the substantial increase in the overall fit of the models when Council formation controls are included indicate that further unobserved factors connected to characteristics of Council formations influence committee decision-making. Thus, the inclusion of these control variables seems warranted.

Table 5 illustrates the substantial effects of the statistically significant estimation results. The table is based on the best-fitting model specification (model 4), which includes the variable indicating the number of policy areas affected as a measure of uncertainty as well as Council formation indicators as control variables. The table presents the changes in the probability that a

Table 5 Effects of changes in the explanatory variables on the probability that a decision is made at the committee level

Council formation

Justice and Internal
Agriculture Environment Home Affairs Market

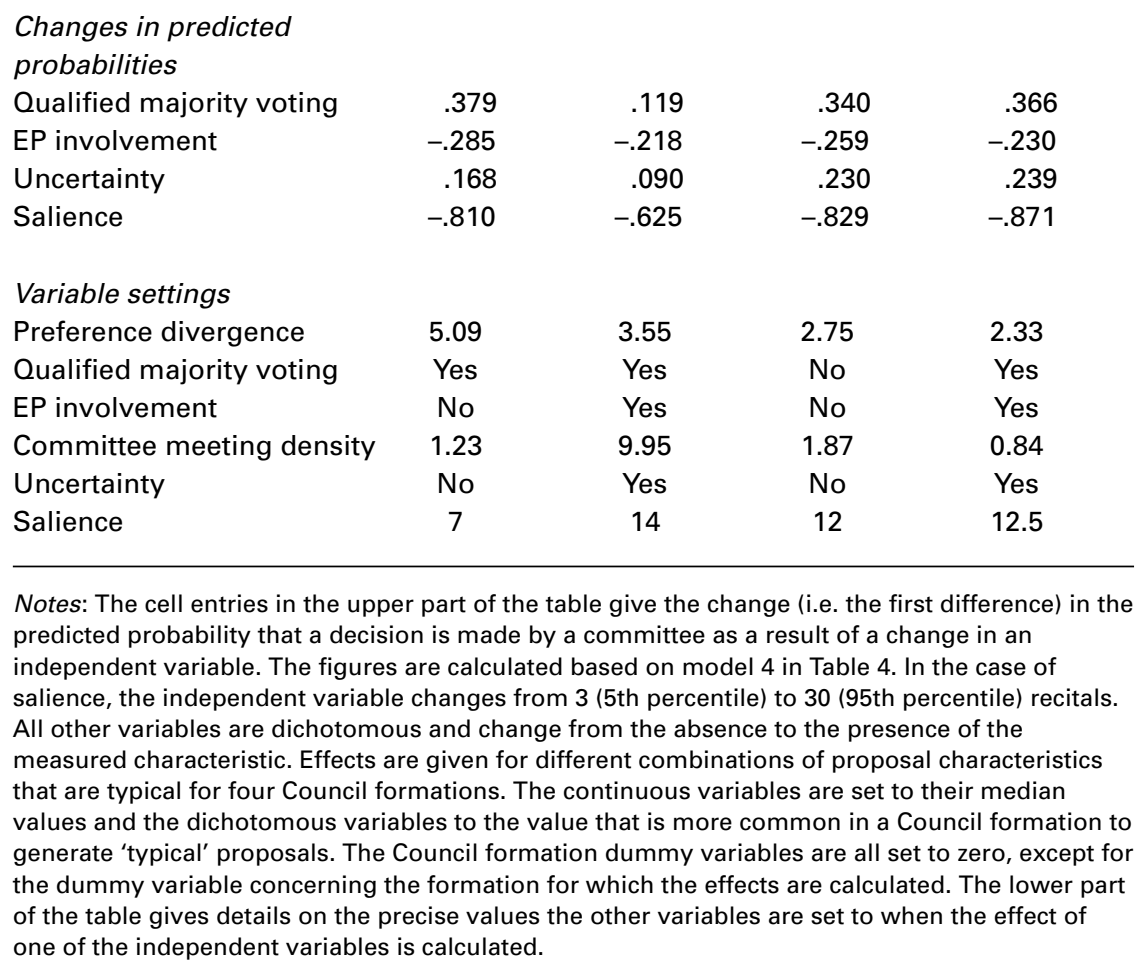


decision is made at the committee level resulting from a change in the value of an independent variable, keeping other independent variables constant at a specified value. The table shows the effects of qualified majority voting, EP involvement, uncertainty and salience given four different combinations of values of the independent variables. The precise values are given in the lower part of the table. Each of these combinations of values of the independent variables corresponds to proposal features that are characteristic of a particular Council formation. Four formations were selected to cover a wide range of values of the independent variables: Agriculture, Environment, Justice and Home Affairs, and Internal Market, Consumers and Tourism. These four formations also represent some of the busiest EU policy areas as far as legislative decision-making is concerned (see Table 1).

In order to generate proposals that are 'typical' of a certain Council formation, continuous independent variables are set to their Council formation specific median values and dichotomous independent variables are set to the value that is more frequently observed in proposals of the Council formation. The dummy variables for different Council formations are all set to zero, except for the dummy variable that indicates the formation for which the effect is calculated. For example, the typical Agriculture dossier is characterized by a relatively strong preference divergence, a rather low number of monthly committee meetings, a very moderate degree of salience, qualified majority voting, no involvement of the EP, and no uncertainty surrounding the consequences of the dossier in question. Given these default values for the independent variables, the upper half of Table 5 indicates that a counterfactual change from unanimity to qualified majority voting increases the predicted probability that a decision is made by a committee by .38 . In contrast, a change from no EP involvement to involvement of the EP results in a decrease of .29. Adding uncertainty increases the predicted probability of a committee decision by .17, whereas an increase in the salience variable from 3 (5th percentile) to 30 recitals (95th percentile) decreases the probability of a committee decision by .81 .

Table 5 indicates a relatively consistent pattern regarding the effect sizes of different variables. Salience is the most important predictor of committee decision-making, followed by the voting rule, EP involvement and uncertainty. All expected effects are of substantial size. Even the smallest effect leads to a change in the predicted probability of a committee decision of 09 .

\section{Summary and conclusion}

Committees play an important role in the decision-making process of the Council of the European Union. Much of the legislation adopted by the 
Council is never discussed by ministers but is de facto decided by member state officials in working parties and the Committee of Permanent Representatives. Although the relevance of committees in Council decision-making is often acknowledged (Westlake and Galloway, 2004: 202), little empirical research has been devoted to the topic. As a contribution to remedy this situation, the study investigated the conditions under which legislative decisions are made at the committee level of the Council hierarchy. Partly based on existing research, several theoretical perspectives on committee decisionmaking in the Council were identified and used to guide the empirical analysis. An original data set of 439 legislative dossiers dealing with different policy matters formed the basis for the statistical enquiry.

The analysis yielded mixed results. Two of the theoretical arguments were not supported by the empirical findings. The analysis gives no support to the notion that committee socialization has an influence on whether or not a decision is made at the committee level in the Council. The rejection of the committee socialization hypothesis does not necessarily mean that committee members do not share supranational norms and values or negotiate in a reciprocal and cooperative manner. But the rejection of the hypothesis does indicate that such cooperative negotiating behaviour is not a result of socialization in EU committees. In this respect, the finding is consistent with other recent research indicating that the socializing effects of international institutions are at best weak (Beyers, 2005; Hooghe, 2005).

The results also indicate that preference divergence among member states does not influence the level at which a decision is reached in the Council. This finding is somewhat surprising, given that only proposals on which no agreement can be found at lower levels in the Council hierarchy are discussed by ministers. Together with the large effect of salience identified in the analysis, this result might indicate that the importance attached to an issue by member states is of more relevance for explaining the internal working of the Council than the member states' positions on the issue.

In accordance with expectations, the findings indicate that the involvement of the EP in the co-decision procedure makes concluding negotiations at the committee level more difficult. Essentially, the co-decision procedure adds a further negotiation partner with veto power. The views of the EP have to be taken into account by member states in order to pass legislation. Committee negotiations are affected when the Council and the EP attempt to reach an early agreement among the two institutions in the first reading of the codecision procedure, or, more indirectly, when member state representatives take account of the future effects of the EP position on the outcome of interinstitutional negotiations while deciding on a common position of the Council.

Although the size of the voting rule effect depends on the inclusion of controls for different Council formations, the possibility of qualified majority 
voting seems to increase the probability of a decision being made at the committee level. Existing accounts of Council decision-making give few indications that the voting rule is explicitly applied to reach decisions at the committee level, but the mere prospect of a vote being taken at the ministerial level seems to foster more compromising attitudes in committee negotiations. The expected effect of uncertainty about the consequences of legislative proposals is also found in the analysis. If a dossier demands more specialized knowledge to understand its consequences, the dossier is more likely to be decided at the committee level. Finally, the single most powerful predictor of committee decision-making is the salience of a dossier. Ministers can devote only a limited amount of time to Council decision-making. Thus, ministers focus their attention on the most consequential proposals and leave less important dossiers for bureaucrats to decide.

The results of the study yield a rather favourable picture regarding the democratic legitimacy of Council decision-making. ${ }^{9}$ Although a considerable proportion of legislative decisions is indeed made by diplomats and national officials, the study finds no evidence that supports the view of government representatives 'going native' in Brussels as a result of participating in committee negotiations. In addition, few commentators would argue against the merits of experts deciding on proposals that demand a good understanding of highly complex matters. Ministers have time constraints and cannot deal with each and every proposal personally. But the analysis demonstrates that the most important dossiers do not go through the Council machinery without the direct involvement of ministers. Thus, government ministers seem to be more in control of Council decision-making than is frequently suggested.

\section{Notes}

I thank Michael Kaeding, Gerald Schneider, Bernard Steunenberg, Dimiter Toshkov, three anonymous referees and the panel participants at the conference of the ECPR Standing Group on EU Politics in Istanbul, the annual conference of UACES in Limerick, and the annual work conference of the NIG in Amsterdam, all held in 2006, for valuable comments and suggestions.

1 Important exceptions include the studies by Beyers and Dierickx $(1997,1998)$, which investigate the communication behaviour of working party members through quantitative network analyses, and the qualitative case studies of decision-making in the Committee of Permanent Representatives conducted by Lewis $(1998,2003,2005)$.

2 For more details on the results of these tests, see the contributions to the special issue 'Winners and Losers of EU Decision Making', vol. 5, issue 1, of 
European Union Politics (2004) and Thomson et al. (2006). The models of König and Proksch (2006a, 2006b) also incorporate a role for the Council's committees in determining the outcome of Council decision-making. However, these models do not yield predictions about the conditions under which agreement will be reached at the committee level.

3 See the 'List of Council Preparatory Bodies', Council document 8605/06. The number includes senior committees (under heading A) but no sub-groups.

4 Only one of the proposals in the sample that had not been discussed by ministers in the first reading was discussed by ministers in later stages of the co-decision procedure. Thus, in practical terms, the focus on first-reading decisions has no substantial effect on the dependent variable or the results of the statistical analysis.

5 The coding procedure is likely to yield figures that exaggerate the influence of ministers. An alternative, relatively reliable procedure codes cases as committee decisions when the committee made the final decision before the dossier was formally adopted. However, this alternative procedure is likely to yield results that overstate the influence of committees. In addition, what exactly a final decision entails in terms of committee influence is often not clear. The types of decision reached by committees after ministerial discussions can range from agreements on substantially important, still outstanding issues to mere finalizations of the precise wording of compromises essentially reached by ministers. In contrast, the coding of cases with no direct ministerial involvement as instances of committee decisions results in values that have a clear meaning and one that is comparable across cases.

6 Because the theoretical argument presumes a direct causal chain between the amount of time spent on committee work, bureaucrats' values and norms, and the type of behaviour bureaucrats consider to be appropriate in committee negotiations, no data on the attitudes of individual bureaucrats are needed to examine this hypothesis.

7 An Excel macro was written in Visual Basic for Applications to extract the raw information automatically. The programme downloads each website contained in the database, searches for the relevant information and copies the information to an Excel sheet. This Excel sheet is then converted to a Stata file for further data processing and the statistical analysis.

8 In spatial modelling terms, the measure corresponds to the 'core'. The core consists of the set of policy alternatives that cannot be beaten by any other alternative in a vote. Although intuitive and easily interpretable, a weakness of the core as a concept of political conflict is its neglect of actors' differential power resources. Power resources are an important feature of bargaining theories of Council decision-making. As an alternative measure of political conflict, the Sigelman and Yough (1978) measure of polarization was calculated, using voting weights of member states as a proxy for bargaining power. The polarization indicator is highly correlated to the core and the results of the analysis are almost identical. The analysis was also repeated using the qualified majority core in cases where qualified majority voting applies, yielding no substantial changes in the results. Finally, all of these measures were recalculated using the government coalition mean rather than the 
position of the responsible minister as the position of a member state. The results of these analyses are also not substantially different from the results using the minister core variable.

9 As one of the reviewers pointed out, the democratic legitimacy of bureaucrats making any legislative decisions at all can be questioned. Although not impossible, changing this practice would require far-reaching modifications of the way in which legislative decision-making is organized in the Council and possibly in the EU in general. The following remarks refer to the democratic legitimacy of Council decision-making given the current institutional structure of the EU. The comments are also restricted to an evaluation of the legitimacy of the process leading up to legislative decisions by the Council. Further legitimacy issues may arise when the implementation of EU legislation in member states is also considered (e.g. König, 2007).

\section{References}

Arregui, Javier, Frans N. Stokman and Robert Thomson (2004) 'Bargaining in the European Union and Shifts in Actors' Policy Positions', European Union Politics 5(1): 47-72.

Arregui, Javier, Frans N. Stokman and Robert Thomson (2006) 'Compromise, Exchange and Challenge in the European Union', in Robert Thomson, Frans N. Stokman, Christopher H. Achen and Thomas König (eds) The European Union Decides, pp. 124-52. Cambridge: Cambridge University Press.

Bailer, Stefanie (2004) 'Bargaining Success in the European Union: The Impact of Exogenous and Endogenous Power Resources', European Union Politics 5(1): 99-123.

Bendor, Jonathan, Amihai Glazer and Thomas H. Hammond (2001) 'Theories of Delegation', Annual Review of Political Science 4: 235-69.

Benoit, Kenneth and Michael Laver (2006) Party Policy in Modern Democracies. London: Routledge.

Beyers, Jan (1998) 'How Supranational Is Supranationalism? National and European Socialization of Negotiators in the Council of Ministers', Acta Politica 33(4): 378-408.

Beyers, Jan (2005) 'Multiple Embeddedness and Socialization in Europe: The Case of Council Officials', International Organization 59(4): 899-936.

Beyers, Jan and Guido Dierickx (1997) 'Nationality and European Negotiations: The Working Groups of the Council of Ministers', European Journal of International Relations 3(4): 435-71.

Beyers, Jan and Guido Dierickx (1998) 'The Working Groups of the Council of the European Union: Supranational or Intergovernmental Negotiations?', Journal of Common Market Studies 36(3): 289-317.

Bostock, David (2002) 'Coreper Revisited', Journal of Common Market Studies 40(2): 215-34.

Checkel, Jeffrey T. (2003) "“Going Native" in Europe? Theorizing Social Interaction in European Institutions', Comparative Political Studies 36(1/2): 209-31.

Cox, Gary W. (2006) 'The Organization of Democratic Legislatures', in Barry R. Weingast and Donald A. Wittman (eds) The Oxford Handbook of Political Economy, pp. 141-61. Oxford: Oxford University Press. 
Cox, Gary W. and Mathew D. McCubbins (2006) Legislative Leviathan: Party Government in the House. Cambridge: Cambridge University Press.

Crombez, Christophe (1996) 'Legislative Procedures in the European Community', British Journal of Political Science 26(2): 199-228.

Crombez, Christophe (1997) 'The Co-Decision Procedure in the European Union', Legislative Studies Quarterly 22(1): 97-119.

Dowding, Keith (2000) 'Institutionalist Research on the European Union', European Union Politics 1(1): 124-44.

Drüner, Dietrich, Ellen Mastenbroek, Gerald Schneider and Torsten J. Selck (2006) 'The Core or the Winset? Predicting Policy Change and Decision Making Efficiency in the EU', mimeo, University of Konstanz, Germany.

Egeberg, Morten (1999) 'Transcending Intergovernmentalism? Identity and Role Perceptions of National Officials in EU Decision-Making', Journal of European Public Policy 6(3): 456-74.

Egeberg, Morten, Günther F. Schaefer and Jarle Trondal (2003) 'The Many Faces of EU Committee Governance', West European Politics 26(3): 19-40.

Elgström, Ole, Bo Bjurulf, Jonas Johansson and Anders Sannerstedt (2001) 'Coalitions in European Union Negotiations', Scandinavian Political Studies 24(2): 111-28.

Epstein, David and Sharyn O'Halloran (1999) Delegating Powers: A Transaction Cost Politics Approach to Policy Making under Separate Powers. Cambridge: Cambridge University Press.

Fouilleux, Eve, Jaques de Maillard and Andy Smith (2005) 'Technical or Political? The Working Groups of the EU Council of Ministers', Journal of European Public Policy 12(4): 609-23.

Franchino, Fabio (2000) 'Control of the Commission's Executive Functions. Uncertainty, Conflict and Decision Rules', European Union Politics 1(1): 63-92.

Franchino, Fabio (2004) 'Delegating Powers in the European Community', British Journal of Political Science 34(2): 269-93.

Franchino, Fabio (2005) 'A Formal Model of Delegation in the European Union', Journal of Theoretical Politics 17(2): 217-47.

Golub, Jonathan (1999) 'In the Shadow of the Vote? Decision Making in the European Community', International Organization 53(4): 733-64.

Häge, Frank M. (2006) 'Who Decides in the Council of the European Union?', Mimeo: Leiden University.

Hagemann, Sara (2005) 'Decision-Making in the European Union's Council of Ministers: New Empirical Findings and Suggestions for a Research Agenda', paper presented at the annual meeting of the Midwest Political Science Association, Chicago, USA.

Hayes-Renshaw, Fiona and Helen Wallace (2006) The Council of Ministers. Basingstoke: Palgrave Macmillan.

Hayes-Renshaw, Fiona, Wim Van Aken and Helen Wallace (2006) 'When and Why the EU Council of Ministers Votes Explicitly', Journal of Common Market Studies 44(1): 161-94.

Hix, Simon (2005) The Political System of the European Union. Basingstoke: Palgrave Macmillan.

Hooghe, Liesbet (2005) 'Several Roads Lead to International Norms, but Few Via International Socialization: A Case Study of the European Commission', International Organization 59(4): 861-98. 
Hooghe, Liesbet, Gary Marks, Marco Steenbergen and Milada Vachudova (2005) 'Chapel Hill Data Set on Positioning of Political Parties on European Integration 2002', University of North Carolina at Chapel Hill, USA. http:/ / www.unc.edu/\%7Ehooghe/parties.htm (consulted on 2 May 2006).

Hörl, Björn, Andreas Warntjen and Arndt Wonka (2005) 'Built on Quicksand? A Decade of Procedural Spatial Models on EU Legislative Decision-Making', Journal of European Public Policy 12(3): 592-606.

Hoyland, Bjorn (2006) 'Allocation of Codecision Reports in the Fifth European Parliament', European Union Politics 7(1): 30-50.

Huber, John D. and Charles R. Shipan (2002) Deliberate Discretion? The Institutional Foundations of Bureaucratic Autonomy. Cambridge: Cambridge University Press.

Johnston, Alastair I. (2001) 'Treating International Institutions as Social Environments', International Studies Quarterly 45(4): 487-515.

Kaeding, Michael (2004) 'Rapporteurship Allocation in the European Parliament', European Union Politics 5(3): 353-71.

Kaeding, Michael and Torsten J. Selck (2005) 'Mapping out Political Europe: Coalition Patterns in EU Decision-Making', International Political Science Review 26(3): 271-90.

Klingemann, Hans-Dieter, Andrea Volkens, Judith Bara, Ian Budge and Michael McDonald (2006) Mapping Policy Preferences II: Estimates for Parties, Electors, and Governments in Eastern Europe, European Union, and OECD 1990-2003. Oxford: Oxford University Press.

König, Thomas (2007) 'Discontinuity: Another Source of the EU's Democratic Deficit?', European Union Politics 8(3): 411-432.

König, Thomas and Mirja Pöter (2001) 'Examining the EU Legislative Process: The Relative Importance of Agenda and Veto Power', European Union Politics 2(3): 329-51.

König, Thomas and Sven-Oliver Proksch (2006a) 'Exchanging and Voting in the Council: Endogenizing the Spatial Model of Legislative Politics', Journal of European Public Policy 13(5): 647-69.

König, Thomas and Sven-Oliver Proksch (2006b) 'A Procedural Exchange Model of EU Legislative Politics', in Robert Thomson, Frans N. Stokman, Christopher H. Achen and Thomas König (eds) The European Union Decides, pp. 211-38. Cambridge: Cambridge University Press.

Krehbiel, Keith (1992) Information and Legislative Organization. Ann Arbor: University of Michigan Press.

Lewis, Jeffrey (1998) 'Is the "Hard Bargaining" Image of the Council Misleading? The Committee of Permanent Representatives and the Local Elections Directive', Journal of Common Market Studies 36(4): 479-504.

Lewis, Jeffrey (2003) 'Institutional Environments and Everyday EU Decision Making. Rationalist or Constructivist?', Comparative Political Studies 36(1/2): 97-124.

Lewis, Jeffrey (2005) 'The Janus Face of Brussels: Socialization and Everyday Decision Making in the European Union', International Organization 59(4): 937-71.

McElroy, Gail (2006) 'Committee Representation in the European Parliament', European Union Politics 7(1): 5-29. 
Mattila, Mikko (2004) 'Contested Decisions: Empirical Analysis of Voting in the European Union Council of Ministers', European Journal of Political Research 43: 29-50.

Mattila, Mikko and Jan-Erik Lane (2001) 'Why Unanimity in the Council? A Roll Call Analysis of Council Voting', European Union Politics 2(1): 31-52.

Pollack, Mark A. (1997) 'Delegation, Agency, and Agenda Setting in the European Community', International Organization 51(1): 99-134.

Rittberger, Berthold (2000) 'Impatient Legislators and New Issue-Dimensions: A Critique of the Garrett-Tsebelis "Standard Version" of Legislative Politics', Journal of European Public Policy 7(4): 554-75.

Schneider, Gerald, Bernard Steunenberg and Mika Widgrén (2006) ‘Evidence with Insight: What Models Contribute to EU Research', in Robert Thomson, Frans N. Stokman, Christopher H. Achen and Thomas König (eds) The European Union Decides, pp. 407-30. Cambridge: Cambridge University Press.

Schulz, Heiner and Thomas König (2000) 'Institutional Reform and DecisionMaking Efficiency in the European Union', American Journal of Political Science 44(4): 653-66.

Selck, Torsten J. (2005) 'Explaining the Absence of Inertia in European Union Legislative Decision-Making', Journal of Common Market Studies 43(5): 1055-70.

Selck, Torsten J. and Bernard Steunenberg (2004) 'Between Power and Luck: The European Parliament in the EU Legislative Process', European Union Politics 5(1): 25-46.

Sigelman, Lee and Syng N. Yough (1978) 'Left-Right Polarization in National Party Systems: A Cross-National Analysis', Comparative Political Studies 11(3): 355-79.

Spence, David B. (2004) 'Negotiations, Coalitions and the Resolution of Inter-State Conflicts', in Martin Westlake and David Galloway (eds) The Council of the European Union, pp. 256-76. London: John Harper.

Steunenberg, Bernard (1994) 'Decision Making under Different Institutional Arrangements: Legislation by the European Community', Journal of Institutional and Theoretical Economics 150(4): 642-69.

Thomson, Robert, Jovanka Boerefijn and Frans Stokman (2004) 'Actor Alignments in European Union Decision Making', European Journal of Political Research 43(2): 237-61.

Thomson, Robert, Frans Stokman, Christopher H. Achen and Thomas König (eds) (2006) The European Union Decides. Cambridge: Cambridge University Press.

Trondal, Jarle (2001) 'Is There Any Social Constructivist-Institutionalist Divide? Unpacking Social Mechanisms Affecting Representational Roles among EU Decision-Makers', Journal of European Public Policy 8(1): 1-23.

Trondal, Jarle (2002) 'Beyond the EU Membership-Non-Membership Dichotomy? Supranational Identities among National EU Decision-Makers', Journal of European Public Policy 9(3): 468-87.

Tsebelis, George (1994) 'The Power of the European Parliament as a Conditional Agenda Setter', American Political Science Review 88(1): 128-42.

Tsebelis, George and Geoffrey Garrett (2000) 'Legislative Politics in the European Union', European Union Politics 1(1): 9-36.

Van Schendelen, Marinus P.M.C. (1996) "“The Council Decides": Does the Council Decide?', Journal of Common Market Studies 34(4): 531-48. 
Westlake, Martin and David Galloway (eds) (2004) The Council of the European Union. London: John Harper.

Zimmer, Christina, Gerald Schneider and Michael Dobbins (2005) 'The Contested Council: Conflict Dimensions of an Intergovernmental EU Institution', Political Studies 53(2): 403-22.

\section{About the author}

Frank M. Häge is a PhD candidate at the Department of Public

Administration, Leiden University, PO Box 9555, 2300 RB Leiden, The Netherlands.

Fax: +31715273707

E-mail: fhaege@fsw.leidenuniv.nl 